\title{
Implementation of financial report and taxation training: performance of MSMEs in Special Region of Yogyakarta
}

\author{
Siti Resmi ${ }^{1}$, Reza Widhar Pahlevi ${ }^{2}$, Fran Sayekti ${ }^{3}$ \\ ${ }^{1}$ Sekolah Tinggi Ilmu Manajemen YKPN, Yogyakarta, Indonesia \\ ${ }^{2}$ Department of Management, Universitas Islam Indonesia, Yogyakarta, Indonesia \\ ${ }^{3}$ Universitas Teknologi Yogyakarta, Yogyakarta, Indonesia \\ *Corresponding author: sitiresmiamp@yahoo.com
}

\begin{abstract}
This study aims to determine and analyze the application of financial report and taxation training for Micro, Small, and Medium Enterprises (MSMEs) as well as any constraints faced ahead. This study observed 25 MSMEs in Special Region of Yogyakarta using a convenience sampling method. The data used are primary data obtained through interviews and focus group discussions. This research used qualitative analysis techniques. The result shows that MSMEs did not keep records because it was difficult and inconvenient. It also found that MSMEs have a tax ID number (NPWP) but did not pay and report their taxes. Tax is perceived as an expense which results in a reduced profit. However, financial reports and knowledge of taxation are required when applying for bank loans and obtaining government incentive funds. With training in the preparation of financial and tax reports, MSMEs are aware of the importance of financial and tax reports. Financial reports, NPWP, and tax return (SPT) filling are factors that can improve their business performance.
\end{abstract}

Keywords: Financial training, taxation training, Micro Small Medium Enterprises

JEL Classification Code: G40, H25, J24 DOI: 10.20885/jsb.vol25.iss1.art5

\section{Introduction}

A financial report is a report producing an useful information to interested parties regarding economic activities and company performance conditions. Until now, there are still many Micro, Small, and Medium Enterprises (MSMEs) that support the nation's economy that has not implemented accounting in running their businesses. The other side of the tax knowledge training for MSMEs is one step to improve the entrepreneur's abilities. Taxes are one of the primary sources of state revenue so that the Government makes every effort to achieve the tax target. Tax is a tool to strengthen the discipline of the society. Sudiartana (2011) mentions some of the causes the Directorate General of Taxes focuses on is the large taxpayers. While MSME supervision has not been optimally carried out, tax compliance of MSME actors is still low.

Based on the field observations took place in Special Region of Yogyakarta, most MSME players, especially the creative industry, have problems in administration and financial reports. They do not have bookkeeping reports that comply with accounting standards. This is due to the development of MSMEs that started from individual businesses, which then developed and took small and medium scale entities. However, calculating payable taxes is difficult for MSMEs with low recording or accounting skills (Anggraini \& Nasution, 2013).

A good understanding of the basic concepts of finance means that when making decisions about finances, there will be no problems in the future to show healthy financial behavior to determine priority needs, not just wants (Xu \& Zia, 2012). In high-income countries, financial literacy is seen as a complement to consumer protection. Whereas in low-income countries, financial outreach is much more limited. The role of financial literacy will help the developing countries to focus more on increasing access to the financial services.

In general, MSMEs often experience delays in their development due to various conventional problems that have not been resolved completely (closed-loop problems). These 
Implementation of financial report and taxation training: performance of MSMEs

in Special Region of Yogyakarta

include problems with human resource capacity, ownership, financing, marketing and other related to business management have prevented MSMEs to compete with large companies. MSMEs in the creative industry tend to have a short-term orientation in making business decisions. Therefore, strategic efforts are needed to increase the competitive advantage of MSMEs. One of the ways that can be done is by enriching the knowledge of MSME players with financial knowledge so that management and accountability can be better accounted for as befits a large company (Resmi et al., 2019).

Several studies have produced positive findings on the importance of MSMEs in financial literacy and taxation. MSMEs that have a good understanding of finance and tax generate business growth (Clark, 2014) and competitive advantage (Bayrakdaroğlua \& San, 2014), recommending the importance of financial literacy in MSME managers with financial training. Managers with higher financial literacy levels show more significant participation in financial markets (Kotzè \& Smit, 2008).

Many MSMEs have not applied the recording of their business financial statements to some extent, impacting the difficulty of obtaining soft credit from financial institutions (Wise, 2013). Apart from that, the need for preparing financial reports for SMEs is not only for the ease of obtaining credit from creditors but for controlling assets, liabilities, and capital as well as income planning and cost efficiency that occurs ultimately as a tool for corporate decision making (Murillo et al., 2020).

However, it is well known that the large tax potential in MSMEs cannot be optimized due to the lack of socialization and a lack of understanding by MSME actors about taxation. The interviews with participants in the tax training program for the fashion business MSME group in Sleman Regency showed that some participants understood taxes but did not pay them. They consider taxes to be a burden on businesses, thereby reducing their profits. In addition, there are MSME actors who are somewhat familiar with taxation but are still hesitant to pay taxes in an orderly manner. MSMEs face problems in the imposition of high tax rates, double taxation, complicated tax regulations, and limited knowledge about taxes. MSMEs realize that taxes are support for state financing, but on the other hand, taxes are a cost for MSMEs so that they hinder their business ability. Therefore, the tax system must be made in such a way as to be competitive and to increase compliance for MSMEs (Ojeka, 2011). This administrative order is a concern that the charge of paying taxes will demand order in administration. This demand for orderly administration is something that is feared by MSME actors. For this reason, it is necessary to slowly but consistently provide assistance and guidance to MSMEs, especially regarding the recording of financial and tax reports (Sandra et al., 2019; Ningrum et al., 2019). The findings of Tee et al. (2016), Atawodi \& Stephen (2012) show that MSMEs experience a decline in business performance due to taxation policies. Therefore, steps are needed to formulate policies that are aligned so that MSMEs can become more effective.

Research on MSME knowledge in understanding the preparation of financial and tax reports is important. Recently, the Government has provided many incentives to MSMEs in various forms. Almost every incentive requires having an NPWP. The consequence of NPWP is taxation obligation in tax payment and reporting. Taxes are closely related to the preparation of financial statements. Tax calculations involve data related to sales, salary expenses, profits, and other expenses. This study aims to determine the extent of knowledge of MSMEs, especially in terms of preparing financial and tax reports. Data were collected through interviews. Interviews were conducted for respondents who attended training in preparing financial reports and tax. With the provision of this training, it is hoped that MSMEs will have a better understanding so that they can get the incentives provided by the Government. Furthermore, incentive funds can be used to improve business performance and win a competition. 


\section{Literature Review}

\section{Tax Training and MSMEs' Performance}

Bandura (1977) states that according to social learning theory, a person can learn through direct observation and experience. The social learning process can be done through continuous reciprocal behavior. The environment is an important factor in shaping behavior. The behavior has consequences for each action taken. The tax learning process can be done through tax training, which will increase the knowledge of taxation. Furthermore, MSMEs are able to understand taxation correctly so that negative perceptions of taxes can be reduced. SMEs worry that taxes will reduce their profits due to limited knowledge of taxes. Given the significant role of the MSME sector in the national economy, it is interesting to look at data on the small number of tax payments from this sector. The number of MSMEs registered by the Ministry of Cooperatives and MSMEs is 60 million, but the MSMEs registered as taxpayers are 2.3 million. In terms of contribution to total tax revenue, most tax revenue is dominated by large taxpayers. UMKM contributed 5-6 trillion rupiahs from the total tax revenue of 1,500 trillion rupiahs (Setiawan, 2020). Newman \& Mwandambira (2018) conducted a study of 30 MSEs and 40 tax officers in Zimbabwe. The result of the research is that knowledge of taxation does not significantly affect tax non-compliance of MSMEs. However, the Government continues to increase awareness of SMEs in paying taxes. In addition, training on recording and taxation continues.

Tax knowledge is very important for a positive attitude and behavior towards tax awareness (Harris, 1989; Eriksen \& Fallan, 1996). An effort that is no less important in increasing tax revenue is socialization through the media. Lack of government socialization regarding tax regulations, tax incentives, and low tax awareness and compliance of MSMEs are suspected as the causes of the potential for state revenue that have not been optimally explored (Grande et al., 2011). Withdrawing taxes from the public, including from MSMEs, is not an easy matter. The low compliance of taxpayers must be addressed with the right strategy to optimize tax revenue while still paying attention to low compliance costs. Most of the MSMEs are home industries. Home industries usually pay less attention to applicable regulations, including tax regulations. Lack of attention to tax regulation is one of the factors of low tax compliance among MSMEs. One of the reasons for this ignorance is a lack of understanding of the applicable provisions; MSME actors are independent businesses with characteristics less obedient than employees whose taxes have been deducted directly from their salaries. Even for taxpayers who report Tax Return (SPT), the absence of comparative data held by the Tax Office makes it challenging to know the correct level of the SPT submitted (Suryarini et al., 2019).

Strong financial knowledge is the primary capital of a country's economy. A tax system suitable for each country can be a potential source of finance. Increasing the tax revenue source can be done by strengthening and expanding MSME businesses (Dolgih et al., 2014). Saad (2014) researched through telephone interviews for 30 respondents. The results showed that the technicality of paying taxes is very difficult, while knowledge of taxes is very limited. This condition contributes to the low level of tax compliance. Experimental research conducted by Nagel (2018) on the Dutch Tax and Customs Administration found that tax training influences tax compliance behavior. However, training has no dominant impact on business continuity. Furthermore, entrepreneurs who received training treatment had a much higher advantage than the control group. Research on the benefits of tax training was also conducted by Andreas \& Savitri (2015). The research result found that tax knowledge affects taxpayer compliance while an NPWP benefits do not affect taxpayer compliance. Tax education will be to improve MSME compliance (Newman, 2018; Maseko, 2014; Berger, 2011). Tax awareness affects tax compliance. It is advised to continue to improve tax socialization and training so that state revenue from the taxation sector can increase. Studies on the influence of tax knowledge and tax compliance have been conducted by many researchers. The results of research for students at several universities show that tax knowledge can 
Implementation of financial report and taxation training: performance of MSMEs

in Special Region of Yogyakarta

improve the tax compliance (Palil \& Mustapha, 2011; Roshidi et al., 2007; Holmes et al. 2012). Knowing the tax regulations properly can improve the performance of MSMEs indirectly. By understanding tax regulations, MSMEs can calculate taxable income correctly, determine the appropriate tax rate, not pay taxes for non-taxable income. MSMEs can also take advantage of incentives in tax reductions and not get sanctions for violating tax regulations. SMEs in Kota Ga Barat cannot enjoy incentives from the government because most of them cannot take advantage of the existing tax system. The loss of this opportunity is due to the lack of education and training for UKM players. Many SMEs in the informal sector cannot get benefits that can increase their business growth (Tee, 2016; Atawodi \& Steven, 2012).

\section{Financial Reports and MSMEs' Performance}

Financial reports contain information about the financial position and financial performance of a business. Financial reports can be used by internal and external users in making financial decisions. For internal users, financial reports help managers find out the profit or loss of a business, observe business developments, predict product selling prices, detect business liquidity, and so on. Financial reports for MSMEs are made based on special standards in the hope that they are easier to understand. The ease and simplicity of these standards are provided to support MSMEs in preparing financial reports. However, there are still many MSMEs did not make financial reports.

Remund (2010), Hasler \& Lusardi (2017) interpret financial knowledge in relation to banking activities, for example: saving, investing, loans, credit, insurance, and financial management. Someone who has deeper financial knowledge and skill is able to handle money efficiently and plan financially optimally (Howlett et al., 2008; Robb \& Woodyard, 2011). People who already have knowledge and skills in the financial sector will apply it in everyday life. They realize the importance of financial knowledge in short and long term decision making (Palameta et.al, 2016).

The level of financial literacy from an individual or family point of view can impact the ability to have long-term savings used to own assets (such as land or a house), the fulfillment of higher education, and old age (pension) funds. Ineffective money management will bring the family into a financial crisis (Braunstein \& Welch, 2002). These findings can also be adapted for companies. In this case, MSMEs that have good financial will achieve their company goal, have a business development orientation, and survive in a difficult economic condition. In the business and entrepreneurship literature, a lack of knowledge and limited access to financial resources have been associated with the failure of companies to achieve their goals (Beck et al., 2005; Hutchinson \& Xavier, 2006; Malo \& Norus, 2009; Coad \& Tamvada, 2012), and the manager's discretion in taking a strategic action (Wiklund et al., 2003).

Some theoretical and research studies explain that a full understanding of financial literacy tends to grow the business growth of the MSMEs. Muraga \& John (2015), in his study, used the variable of debt management, budgeting, bank service, and accounting or recording as financial literacy found that all variables of financial literacy have a positive relationship with business performance. Aribawa (2016) found that financial literacy affects the performance and business sustainability of Creative MSMEs. It is also added by Lusimbo \& Muturi (2016) that managers with low financial literacy recorded lower, even zero business growth. The finding from Bayrakdaroğlua \& Şan (2014) explained that MSMEs in developing countries, especially Turkey, show a way to improve the managers' financial literacy is through financial training. Financial literacy needs to be provided early for all groups. Financial literacy instills financial confidence that can empower a person to explore entrepreneurial skills. Thomas \& Subhashree (2020) found that financial knowledge affects the level of financial literacy of engineering undergraduate students. Research on engineering students was carried out because there were great opportunities for engineering graduates to become entrepreneurs. 


\section{Methods}

This research is a case study research. Case study research examines a particular case or phenomenon that exists in society. An in-depth research is carried out to study the background, circumstances, and interactions occured among the variables. The case study in question can be in the form of a unified system which can be a program, activity, event, or a group of individuals who exist in certain circumstances or conditions. Case study research does not have to examine only one person or individual, but it can be conducted with several people or objects that have a single focus on a particular phenomenon. This case study research used interview, observation, and documentary study techniques to obtain in-depth data. The data was then analyzed and interpreted in order to understand a certain phenomenon being studied.

This study used primary data. The data were the results of interviews and focus group discussions. with the owner or managers of MSMEs. Interviews were conducted for 20 MSMEs. The interview process was preceded by providing training on financial reporting and tax knowledge. Training is given to MSME groups for the entire province of D.I. Yogyakarta. The training and discussion were held eight times, with around 25 MSMEs each time. In training, several MSMEs asked questions and clarified the training materials given. Those who were actively discussing and asking questions were specifically interviewed with more detailed questions. The results of the interviews were recorded and summarized to be used as statements as research data. Most of MSMEs as respondents (80\%) are business owners, while the rest (20\%) are employees. Respondents of this research are MSMEs which are engaged in fashion and restaurant businesses. For the restaurant business, the largest revenue comes from catering services. Meanwhile, for the fashion business, the products are sold on a season by adjusting to the current situation. Respondents are not a long-term permanent employees. Routine activities are carried out with family and one or two employees on a daily basis. If orders are received, they employ a lot of freelance workers. Recording activities are carried out if there is a need that requires recording, for example when applying for credit at a bank and submitting a grant from the government. All respondents must have the NPWP as a requirement to get orders, especially those from the government. However, they do not know what kind of obligation attached on having the NPWP.

\section{Result and Discussion}

Knowledge sharing to MSMEs should be done not only from the government, academician, or more significant business. It is essential to understand that intra-MSME cooperation is necessary to achieve complementary capabilities (Resmi et al., 2019). Correspondingly, the issues that lowliterates face are often multifaceted and highly context-dependent. Different low-literate people will encounter different problems, depending on their cultural background, educational history, vocabulary, and pre-existing skills. Because of these issues, it is challenging to provide effective learning. Traditionally, high learning effectiveness is equated with an education that focuses on desired, meaningful learning outcomes (Monticone, 2010). MSMEs will have a competitive advantage when they have good literacy in financial (Muraga \& John, 2015). However, if MSMEs are reluctant to learn and add knowledge about finance, it could significantly affect their performance (Lusimbo \& Muturi, 2016). The government and universities, especially in developing countries, also need to provide support for MSMEs in various ways, such as training and mentoring (Potrich et al., 2015). It will give more encouragement to manage the business seriously, provide satisfying service to stakeholders, and manage company risk (Nunoo \& Andoh, 2012). Financial education inclusion into the primary and secondary school curriculum has been an enormous step forward because prevention seems to be the most effective measure. Children learn financial literacy before they have their financial responsibility or negative experience with the world of money. They will not manage financial issues until they become adults, but they will already be aware of the possible risks by then. Thus, we can assume that the generation which takes financial 
Implementation of financial report and taxation training: performance of MSMEs

in Special Region of Yogyakarta

education courses will be better prepared for life, and only with them will the situation in this area significantly improve (Opletalová, 2015).

Even though MSMEs only do simple bookkeeping, they still have to calculate both operational and non-operational expenses so that MSMEs receive the actual. Financial training is deemed necessary for both advanced MSMEs and those still starting MSME businesses. The financial statements should consist of an income statement, a statement of changes in retained earnings, a statement of financial position, a cash flow statement and notes to the financial statements. MSMEs do not need to make all of the reports above but at least prepare an income statement and a statement of financial position. Some MSMEs have an useful financial report but do not calculate and pay taxes correctly. These MSMEs play a very important role in future economic progress because they can support people's lives at large. The role of MSMEs in the future is also as stabilizers and drivers of economic growth. UMKM is expected to increase the standard of living and welfare of the nation. The development of digital economy-based MSMEs will indirectly help the regional economy. The development of MSMEs using a digital basis will also have a positive impact on Indonesian taxation.

The Indonesian government is increasingly encouraging the development of MSMEs through easy access to taxation with a smaller final tax rate. The ease and simplification of the MSMEs tax rules aim to create administrative order, transparency, and increase the community's contribution, especially MSME entrepreneurs, to taxes in Indonesia (Suryarini et al., 2019).

However, ironically, the thing felt by one of the MSME players engaged in packaged food in the city of Yogyakarta states that "Taxes are something that must be spent and are considered to get rid of bad luck." Currently, he has not processed taxes, but will take care of them later because taxes will facilitate all of his business affairs".

Another thing is also expressed by business actors in Sleman Regency, that "The income is still minimal if asked to pay taxes, how much will the profit be? Feel so afraid of paying taxes".

They joined this tax training because they wanted to know how much the tax they should pay. Based on the perceptions felt by the business actors, tax training is needed. At the time of the socialization, he explained the importance of taxes for Indonesia's development. Although the community, if the tax is managed correctly, it will benefit development in Indonesia, especially in Special Region of Yogyakarta. This socialization also explained the types of central and regional taxes in which the regional government would manage the regional tax for local community welfare. The socialization is done to increase public awareness of the importance of taxes. The obedience of business actors to tax administration is also beneficial for business actors themselves in obtaining easy access to capital. Banks and other financing institutions will assess the track record of the business whether the business actor is tax compliant, including NPWP ownership, reporting compliance, and tax payment compliance. The socialization process ran smoothly and was attended by micro, small and medium enterprises. After the socialization of awareness, understanding, and compliance of MSMEs with taxes, the public began to realize the importance of taxes for development and the ease of access to capital. Participants also understand the amount of the final MSME tax rate of $0.5 \%$ of Gross Income according to Government Regulation PP 23/2018 concerning Income Taxes from Businesses Received or Obtained by Taxpayers with Certain Gross Turnover.

Tax awareness has been understood by several MSME business actors in Kulonprogo or Sleman Regency. It is stated that "Those who have the NPWP are aware of the obligation to pay tax but still feel that paying taxe is difficult due to its administrative mechanism".

According to Suryarini et al. (2019), the potential number of MSMEs, which is quite large in Indonesia provides an opportunity for the government to get tax revenue from MSMEs. Therefore, training and assistance are needed to improve the level of understanding, awareness and compliance of taxes for MSMEs. Tax training is essential to be carried out, considering the self-assessment system adopted by Indonesia. This system requires taxpayers to understand, be aware of, be honest, 
desire and have an ability to calculate, report and pay their taxes so that it will make it easier for MSME business actors.

The majority of MSME actors in Special Region of Yogyakarta are somewhat familiar with taxation but still hesitant to pay taxes in an orderly manner. There is a concern that orderly paying taxes will demand a complicated tax administration. This tax administration demand is something that is feared by MSME actors. For this reason, it is necessary to slowly but consistently provide assistance and guidance to MSMEs. Training by guiding to fill in ID Billing for mass SPT payments. MSMEs are given guidance to fill in mass SPT billing IDs. The stages: (a) the device must be connected to the internet; (b) open the sse.pajak.go.id application. (c) clicking the "version 2" option; (d) fill in the data according to the available forms, including NPWP, password, name of taxpayer, which will automatically guide to the link in question; (e) Select payment type 41128 final tax and tax type 420 tax with particular gross circulation; (f) fill in the tax period; (g) fill in the deposit amount; and (h) click on the bottom right of "ID billing".

MSME business actors who already have an NPWP and if they have carried out their obligations regularly by submitting an annual SPT, it is said that the business actor will feel more comfortable, the business actor will know the level of profit or loss generated so that it will be easy to evaluate performance. In addition, the advantage of having an orderly tax administration and already having an NPWP is that businesses can get additional external funds. Additional external funds are one of the needs of MSMEs in developing their business. The first objective relates to provisions that require a company to fulfill its obligations, such as paying taxes, carrying out social and environmental responsibilities, and complying with labour provisions such as security and other workers' rights. Meanwhile, the second objective is more focused on policy-making, such as coaching efforts, increasing technical capabilities, and financing policies for MSMEs (Xiao et al, 2015).

As previously explained, MSME owners have limited administrative capabilities and financial report preparation. Problems faced such as recording profit or loss statements, separation of capital, calculating accumulated depreciation of machines, determining prices, determining profit margins, the concept of assets and capital are obstacles for MSME actors. With these limitations, MSME owners are required to use consultant services. Sometimes the consulting services used are burdensome for MSME owners. The financial problems associated with MSMEs are slightly different from those of large-scale enterprises. Large-scale businesses generally use the accrual method in their accounting records. In contrast, MSMEs generally use a cash-based method to recognize income and expense when cash is received or disbursed. Financial recording and reporting is very useful for the decision-making process of a business. Financial information is used to consider the continuity of a business. Although accounting provides benefits to the success of the business, many MSMEs have not implemented accounting in their business (Murillo et al., 2020).

Most entrepreneurs do not know the profit they will get; they answer not with the nominal rupiah figures but with tangible objects such as motorbikes, houses, or cars. This answer does not describe the company's actual profit because it is one of the use of funds that may be funded from debt, or taking the owner's capital. The assets owned can come from the sale of other assets, acceptance as an employee, inheritance, or loan. The ignorance of these assets' origin is because MSMEs do not record the separation of assets and debts of companies and owners. According to Anggraeni (2015), Financial literacy education needs to be aimed at MSME owners so that business actors become more familiar with finance. Literacy education includes financial management, financial recording, and financial planning. Financial recording will make it easier for banks in Indonesia to channel credit to these business actors. So far, the banks' obstacles in extending credit are low financial literacy and the absence of recording business transactions. Any additional capital disbursement will provide an injection to increase the flow of funds. The research result by Carpena et al. (2017) shows that the level of business owners' financial is low so that it affects the ability to manage finances. 
Irregular administration is reflected in the results of the business owner's financial attitude which is only limited to recording business financial receipts and expenditures without being accompanied by the storage of supporting documents (Di Girolamo et al., 2015). So far, business owners have never made a budget as a basis for evaluating their business performance. In addition, the ability of business owners to manage cash surpluses and deficits shows that the majority use banking or non-banking services. They are not yet at the stage of investing in financial products. Training on procedures for preparing financial reports by financial accounting standards is a form of improving the quality of financial statement, which will have an impact in increasing the credibility of MSME financial reports. Training on the understanding of financial reporting based on Financial Accounting Standards can help MSME players prepare their financial reports appropriately so that they can quickly gain access to capital from banks. A good understanding of financial literacy helps MSMEs to access and optimize every opportunity that exists in the financial industry. In addition, MSMEs can maximize their performance in realizing advanced and independent businesses.

\section{Conclusion}

This study emphasizes the importance of MSME knowledge in preparing financial reports and tax obligations. Data was collected through in-depth interviews with 20 MSMEs who attended training in preparing financial and tax reports. The results obtained are that MSMEs do not record business finances. Financial records are felt to be troublesome and difficult. The main focus of MSMEs is to market products. However, when applying for credit and applying for financial assistance from the government, they feel the importance of having financial reports. All respondents have a NPWP. NPWP is needed for the requirements for getting orders, especially related to government spending. In addition, having an NPWP is intended to meet the requirements for obtaining funds from banks and to get incentives from ministries or other parties. They do not realize the obligations that must be fulfilled with the ownership of the NPWP. Financial report preparation training opens MSME insights in understanding the importance of having financial reports. Financial information can be used as a basis for analysis of selling price, calculating profit, and asset development. By understanding financial reports, MSMEs can improve their business performance. Tax education is important because in the future, the government will make various efforts to increase revenue from the tax sector. MSMEs are the government's flagship business which is expected to contribute to the national economy. Therefore, MSMEs really need the knowledge of taxation. Through taxation training, MSMEs become aware of the obligations that must be fulfilled. There are many benefits to be tax-compliant. Tax is a burden which is always be avoided by MSMEs. However, tax avoidance will have negative, direct or indirect consequences. Tax avoidance can result in the imposition of tax fines and sanctions.

The managerial implication of this study is that the comprehensive understanding of financial reports and taxation for MSMEs can improve the MSMEs' performance. Preparation of good financial reports and understanding taxation correctly can be done through ongoing training and mentoring programs. They do not comply with taxation provisions because there is an ignorance. Poor understanding of taxation and financial report will result in the negative perceptions of taxation and financial reports.

\section{Acknowledgment}

The research team would like to express gratitude to the Directorate of Research and Community Service, Directorate General of Research and Development at the Ministry of Research, Technology, and Higher Education for providing financial assistance during the research output process in the Basic Research Grant 2020/2021 scheme. 


\section{References}

Andreas \& Savitri, E. (2015). The Effect of Tax Socialization, Tax Knowledge, Expediency of Tax ID Number, and Service Quality on Taxpayers Compliance with Taxpayers Awareness as Mediating Variables. Procedia - Social and Behavioral Sciences, 211, 163-169. DOI: 10.1016/j.sbspro.2015.11.02.

Anggraeni, B. D. (2015). Pengaruh Tingkat Literasi Keuangan Pemilik Usaha terhadap Pengelolaan Keuangan. Studi Kasus: UMKM Depok. Jurnal Vokasi Indonesia, 3(1), 22-30.

Anggraini, D., \& Nasution, H. (2013). Peranan Kredit Usaha Rakyat (KUR) bagi Pengembangan UMKM di Kota Medan (Studi Kasus Bank BRI). Ekonomi dan Keuangan, 1(3), 105-116.

Aribawa, D. (2016). The Effect of Financial Literacy on the Performance and Sustainability of MSMEs in Central Java. Journal of Business Strategy, 20(1), 1-13.

Atawodi, O. W., \& Stephen, A. O. (2012). Factors that Affect Tax Compliance among Small and Medium Enterprises (SMEs) in North Central Nigeria. International Journal of Business and Management, 7(12), 87- 96. DOI:10.5539/ijbm.v7n12p87.

Bandura, A. (1977). Social Learning Theory. Prentice-Hall, Inc., New Jersey.

Bayrakdaroğlua, A., \& Şan, F.B. (2014). Financial Literacy Training as A Strategic Management Tool Among Small- Medium Sized Businesses Operating in Turkey. Procedia-Social and Behavioral Sciences, 150, 148-155.

Beck, T.A., Demirguc-Kunt., \& Maksimovic, V. (2005). Financial and Legal Constraints to Growth: Does Firm Size Matter? The Journal of Finance, 60(1), 137-177.

Berger, T. (2011). Tax hangover or cure? Reforms for research and development tax incentive. Australian Intellectual Property Law Bulletin, 24(2), 39-41.

Braunstein, S. \& Welch, C. (2002). Financial Literacy: An Overview of Practice, Research, and Policy. USA: Federal Reserve Bulletin.

Carpena, F., Cole, S., Shapiro, J., \& Zia, B. (2017). The Financial Education: Experimental Evidence on Attitudes, Behavior, and Cognitive Biases. Management Science, 65(1), 346-369.

Clark, G.L. (2014). Roepke Lecture in Economic Geography-Financial Literacy in Context. Economic Geography, 90(1), 1-23. https://doi.org/10.1111/ecge.12029

Coad, A., \& Tamvada, J. P. (2012). Firm Growth and Barriers to Growth among Small Firms in India. Small Business Economics, 39(2), 383-400.

Di Girolamo, A., Harrison, G.W., Lau, M.I., \& Swarthout, J.T. (2015). Subjective Belief Distributions and The Characterization of Economic Literacy. Journal of Behavioral and Experimental Economics, 59, 1-12.

Dolgih, I.N., Zhdanova, A.B., \& Bannova, K.A. (2014). The influence of taxation on small enterprise development in Russia. Procedia - Social and Behavioral Sciences, 166, 216 - 221. http://creativecommons.org/licenses/by-nc-nd/3.0/.

Eriksen, K. \& Fallan, L. (1996). Tax knowledge and attitudes towards taxation: A report on quasi experiment. Journal of Economic Psychology, 17(3), 387- 402.

Grande, J., Madsen, E. L., \& Borch, O. J. (2011). The Relationship between Resources, Entrepreneurial Orientation, and Performance in Farm-Based Ventures. Entrepreneurship \& Regional Development: An International Journal, 23(3), 89-111. 
Harris, T.D. (1989). The effect of type of tax knowledge on individuals' perceptions of fairness and compliance with the federal income tax system: An empirical study. PhD Thesis, University of South Carolina.

Hasler, A., \& Lusardi, A. (2017). The Gender Gap in Financial Literacy: A Global Perspective. Global Financial Literacy Excellence Center, The George Washington University School of Business.

Hutchinson, J., \& Xavier, A. (2006). Comparing the Impact of Credit Constraints on the Growth of SMEs in a Transition Country with an Established Market Economy. Small Business Economics, 27(2), 169-179.

Howlett, E., Kees, J., \& Kemp, E. (2008). The Role of Self-Regulation , Future Orientation, and Financial Knowledge in Long-Term Financial Decisions. The Journal of Consumer Affair, $42(2), 223-242$.

Holmes, K., Marriot, L., \& Randal, J. (2012). Ethics and experiments in accounting: A contribution to the debate on measuring ethical behaviour. Pacific Accounting Review, 80-100.

Kotzè, L., \& Smit, A.V.A. (2008). Personal Financial Literacy and Personal Debt Management: The Potential Relationship with New Venture Creation. The Southern African Journal of Entrepreneurship and Small Business Management, 1(1), 35-50. DOI: https://doi.org/10.4102/sajesbm.v1i1.11.

Lusimbo, E.N., \& Muturi, W. (2016). Financial Literacy and The Growth of Small Enterprises in Kenya: A Case of Kakamega Central Sub-County, Kenya. International Journal of Economics, Commerce, and Management, 4(6), 828 - 845.

Malo, S., \& Norus, J. 2009. Growth Dynamics of Dedicated Biotechnology Firms in Transition Economies. Evidence from the Baltic Countries and Poland. Entrepreneurship and Regional Development, 21(5), 481-502.

Maseko, N. (2014). The impact of personal tax knowledge and compliance costs on tax compliance behaviour of SMEs in Zimbabwe. Elite Research Journal of Accounting and Business Management, 2(3), 26-37.

Monticone, C. (2010). How Much Does Wealth Matter in The Acquisition of Financial Literacy? Journal of Consumer Affairs, 44(2), 403-422. DOI: https://doi.org/10.1111/j.1745-6606. 2010.01175.x.

Muraga, K.P., \& John, N. (2015). Effects of Financial Literacy on Performance of Youth Led Entreprises: A Case of Equity Group Foundation Training Program in Kiambu County. International Journal of Social Sciences Management and Entrepreneurship, 2(1), 218-231.

Murillo, Pilar, M. M., Francob, A., Diego, \& Tobón, R. (2020). The Role of Cognitive Abilities on Financial Literacy: New Experimental Evidence. Journal of Behavioral and Experimental Economics, 84, 101- 482.

Nagel, H., Laura, R.H., Van, P., \& Sjoerd, G. (2018). The effect of a tax training program on tax compliance and business outcomes of starting entrepreneurs: Evidence from a field experiment. Journal of Business Venturing, 34(2), 1-22. DOI: https://doi.org/10.1016 /j.jbusvent.2018.10.006.

Newman, W., \& Mwandambira, N. (2018). Evaluating the impact of tax knowledge on tax compliance among small medium enterprises in a developing country. Academy of Accounting and Financial Studies Journal, 22(6). 1-14. 
Ningrum, E. P., Tutiek, Y., Nurul R., Widi, W., \& Novita, W. S. (2019). Pelatihan Pembukuan Sederhana, Sosialisasi Perpajakan dan Pengelolaan Manajemen bagi UMKM Ibu-lbu Catering Perumahan Jatimulya RW. 012. Jurnal Pengabdian kepada Masyarakat ABDIMAS UBJ, 126-130.

Nunoo, J. \& Andoh, F.K. (2012). Sustaining Small and Medium Enterprises Through Financial Service Utilization: Does Financial Literacy Matter? Agricultural \& Applied Economics Association's 2012 Annual Meeting, Washington.

Ojeka, S. A. (2011). Tax Policy and the Growth of SMEs: Implications for the Nigerian Economy. Research Journal of Finance and Accounting, 2(2), 1-12.

Opletalová, A. (2015). Financial Education and Financial Literacy in the Czech Education System. Procedia - Social and Behavioral Sciences, 171, 1176 - 1184.

Palameta, B., Nguyen, C., Hui, T. S., Gyarmati, D., Wagner, R. A., Rose, N., \& Llp, F. (2016). The link between financial confidence and financial outcomes among working-aged Canadians.

Palil, M. R., \& Mustapha, A. F. (2011). Factors affecting tax compliance behaviour in selfassessment system. African Journal of Business Management, 5(33), 12864-12872.

Potrich, A.C.G., Vieira, K.M., Coronel, D.A., \& Bender F. R. (2015). Financial Literacy in Southern Brazil: Modeling and Invariance between Genders. Journal of Behavioral and Experimental Finance, 6, 1-12.

Resmi, S., Reza W. P., \& Fran S. (2019). The Effect of Financial and Taxation Literacy on Sustainable Competitive Advantage Through Business Growth: A Study of Creative Msmes in Special Region of Yogyakarta, Indonesia. International Journal of Entrepreneurship, 23(4), 1-9.

Remund, D. L. (2010). Financial Literacy Explicated: The Case for a Clearer Definition in an Increasingly Complex Economy. The Journal of Consumer Affair, 44(2), 276-295.

Robb, C. A., \& Woodyard, A. S. (2011). Financial Knowledge and Best Practice Behavior. Journal of Financial Counseling and Planning, 22(1), 60-70

Roshidi, M. A., Mustafa, H., \& Asri, M. (2007). The effects of knowledge on tax compliance behaviours among Malaysian taxpayers. Business and information, 4(1).

Saad, N. (2014). Tax Knowledge, Tax Complexity, and Tax Compliance: Taxpayers' View. ProcediaSocial and Behavioral Sciences, 109, 1069 - 1075. DOI: 10.1016/j.sbspro.2013.12.590.

Sandra, A., Hanif, Rizka, I. A., \& Prima A. (2019). Pendampingan Pajak UMKM: Masalah dan Solusinya. Academics in Action Journal, 1(1), 1-7.

Setiawan, D. A. (2020). Dinilai 'Tahan Banting', Kontribusi UMKM ke Pajak Diharapkan Naik. https://news.ddtc.co.id/dinilai-tahan. Retrieved October $20^{\text {th }}, 2020$.

Sudiartana, I. M. (2011). Faktor-Faktor yang Mempengaruhi Kepatuhan Wajib Pajak. Accounting and Tax Review, 7(2), 44-54. DOI: https://doi.org/ISSN 0854-1981.

Suryarini, T., Badingatus S., \& Ain H. (2019). Pendampingan Pelaporan Pajak bagi UMKM di Karimunjawa. Seminar Nasional Kolaborasi Pengabdian kepada Masyarakat UNDIP-UNNES 2019.

Tee, E., Doadi, L. A., Opoki, R. T. (2016). The Effect of Tax Payment on the Performance of SMEs: The Case of Selected SMEs in Ga West Municipal Assembly. European Journal of Business and Management, 8(20), 119-125. 
Thomas, B., \& Subhashree, P. (2020). Factors that Influence the Financial Literacy among Engineering Students. Procedia Computer Science, 172, 480-487. DOI: 10.1016/ j.procs.2020.05.161.

Wiklund, J., Davidsson, P., \& Delmar, F. (2003). What do they think and feel about growth? An expectancy-value approach to small business managers' attitudes toward growth. Entrepreneurship Theory and Practice, 27(3), 247-270.

Wise, S. (2013). The Impact of Financial Literacy on New Venture Survival. International Journal of Business and Management, 8(23), 30-39.

Xiao, J.J., Chen, C., \& Sun, L. (2015). Age Differences in Consumer Financial Capability. International Journal of Consumer Studies, 39(4), 387-395. DOI: https://doi.org/10. 1111/ijcs. 12205.

Xu, L., \& Zia, B. (2012). Financial Literacy Around the World: An Overview of the Evidence with Practical Suggestions for the Way Forward. Policy Research Working Paper, 1-58. Washington, DC: World Bank. 